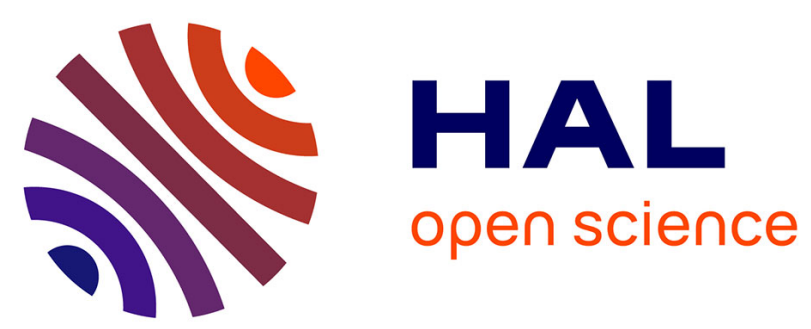

\title{
Global Health Governance
}

Wolfgang Hein, Lars Kohlmorgen

\section{To cite this version:}

Wolfgang Hein, Lars Kohlmorgen. Global Health Governance. Global Social Policy, 2008, 8 (1), pp.80-108. 10.1177/1468018107086090 . hal-00571812

\section{HAL Id: hal-00571812 \\ https://hal.science/hal-00571812}

Submitted on 1 Mar 2011

HAL is a multi-disciplinary open access archive for the deposit and dissemination of scientific research documents, whether they are published or not. The documents may come from teaching and research institutions in France or abroad, or from public or private research centers.
L'archive ouverte pluridisciplinaire HAL, est destinée au dépôt et à la diffusion de documents scientifiques de niveau recherche, publiés ou non, émanant des établissements d'enseignement et de recherche français ou étrangers, des laboratoires publics ou privés. 


\title{
Global Health Governance
}

\section{Conflicts on Global Social Rights}

\author{
WOLFGANG HEIN AND LARS KOHLMORGEN \\ GIGA German Institute of Global and Area Studies, Germany
}

\begin{abstract}
Aв STRACT This article analyses the impact of new institutional structures in global health governance (GHG) on the realization of social rights in poor countries. Focusing on the example of global HIV/AIDS politics. The article argues that new governance modes increase the participation of civil society groups and affected communities, but also that they are frequently instrumentalized by powerful actors to pursue their particular interests. In fact, increasing resources are mobilized for the fight against poverty-related diseases. The article concludes that, as the experience of HIV/AIDS politics, the conflicts around the TRIPS Agreement and the development of Global Public-Private Partnerships GPPPs suggest, GHG is characterized by a combination of moral values and material interests that does not guarantee a comprehensive realization of social rights, but which allows some progress in the fight against poverty-related diseases - a step toward realization of social rights.
\end{abstract}

KEYWORDS developing countries, global bealth governance, global social rights, HIVIAIDS politics, international organizations, new governance modes

\section{Introduction}

Article 25 of the Universal Declaration of Human Rights states that: 'Everyone has the right to a standard of living adequate for the health and well-being of himself and of his family, including food, clothing, housing and medical care and necessary social services ... '. This right was reinforced by 
Art. 12 of the International Covenant on Economic, Social and Cultural Rights (ESCRs), a legally binding instrument concluded in 1966 and ratified by all Organisation for Economic Co-operation and Development (OECD) countries with the exception of the USA. In the 1970s, international discussions about a new international economic order and the World Bank's basic needs strategy focused at least partially on the need to help developing countries fulfil the duties they had taken on with this covenant. Later on, however, the politics of neoliberal globalization (trade liberalization, structural adjustment) gave little priority to global social rights, the fulfilment of which was rather seen as a consequence of economic growth.

At present, the strong focus on the Millennium Development Goals indicates that it has again become widely acknowledged that there is a need for addressing social and economic rights more directly. Four developments can be seen as the cornerstones that characterize the problems and opportunities for progress in this field:

1. An extensive body of legal contracts defining the rules of the international economic system with the aim of laying the basis for a liberalized global economy has been consolidated - basically the World Trade Organization (WTO) Agreements.

2. We find a renewed and strengthened concern for global social justice as an essential value, on the intellectual level as well as on the level of global civil society activities as a reaction to the growing social and economic inequality accompanying the process of economic globalization. Globalized communication and social interactions have increased the awareness of the scandal of widespread poverty and poverty-related illnesses. Civil society actors - particularly non-governmental organizations (NGOs) - gained more importance in global politics due to a lack of emphasis on these issues by many 'traditional' international governmental organizations (IGOs) and nation states in the 'high time' of neoliberalism during most of the 1980s and 1990s. Additionally, some IGOs are weakened by a growing mistrust by powerful member states, a tightening of budgets and inflexibilities in decision-making (cf. Rittberger and Zangl, 2006).

3. Since the later 1990s, however, IGOs - in particular the World Bank - as well as OECD governments have been giving higher priority to strategies to fight poverty and to improve health in poor countries and are increasingly reacting favourably to human-rights based policy approaches (see for example the focus on equity and the references to human rights in the World Development Report 2006). This can be explained by the increasing power of advocacy-oriented Civil Society Organizations (CSOs) (O'Brien et al., 2000), but also by the increasing perception of poverty and health problems as threats to security (see e.g. Barnett, 2006; Ostergard, 2002; Peterson, 2002; Prins, 2004; Wolfensohn, 2004). 
4. In the last 20-5 years, institutional changes in international politics have generated a multi-actor constellation and a developing system of global governance (cf. Held and McGrew, 2002; Koenig-Archibugi and Zürn, 2006; Rosenau, 1997; Wilkinson, 2005). This multi-actor constellation is particularly pronounced in global health governance (GHG) (cf. Hein et al., 2007). This is a field where deep-reaching institutional changes can be observed that reflect new challenges of globalization, but also an increasing global interdependence due to a densification of social interactions in an emerging global society. ${ }^{1}$

In this article we will look at the rise of GHG, concentrating on the rise of new institutional structures in the field of HIV/AIDS, but also looking at the wider impact of these developments on the realization of the right to health.

In the first section, we present the basic articles of human rights documents related to global health. This is followed by a summary of the new challenges posed to global health by globalization and by the new institutional developments in GHG in section two. We demonstrate this institutional setting more closely by focusing on the problem of access to medication in the context of HIV/AIDS. In the following sections, three to five, we look at the central problems with which global social policies are confronted: the issue of defending social goals in the face of global trade rules aimed at the creation of global markets, particularly with the Agreement on Trade-Related Intellectual Property Rights (TRIPS) (section three), as well as the issue of mobilizing resources to finance health care in poor countries, i.e. issues of redistribution. Section four analyses Global Public-Private Partnerships (GPPPs) as initiatives that give the pharmaceutical industry an opportunity to express corporate responsibility, and section five discusses the role of various types of actors in the broader perspective of mobilizing funds for the fight against HIV/AIDS. Finally, section six concludes that GHG has developed as a 'patchwork of compromises'.

\section{Globalization, Social Rights and Health}

The International Covenant on Economic, Social and Cultural Rights states that all 'States Parties recognize the right of everyone to the enjoyment of the highest attainable standard of physical and mental health' (Art. 12.1), which includes 'the prevention, treatment and control of epidemic, endemic, occupational and other diseases' as well as 'the creation of conditions which would assure to all medical service and medical attention in the event of sickness' (Art. 12.2) (http://www.unhchr.ch/html/menu3/b/a_cescr.htm). These documents, however, are rather inconclusive with respect to the 'standard of health' that is supposed to be 'attainable'. The Committee on Economic, Social and Cultural Rights (CESCR), which was established to carry out the 
monitoring functions assigned to the United Nations Economic and Social Council (ECOSOC) in the Covenant, also publishes interpretations of its provisions in the form of general comments. These can be seen as 'more or less authoritative statements of interpretation' (Steiner and Alston, 2000: 265). In 2000, the CESCR adopted a 20-page document on 'The right to the highest attainable standard of health', ${ }^{2}$ stating that:

If resource constraints render it impossible for a State to comply fully with its Covenant obligations, it has the burden of justifying that every effort has nevertheless been made to use all available resources at its disposal in order to satisfy, as a matter of priority, the obligations outlined above. It should be stressed, however, that a State party cannot, under any circumstances whatsoever, justify its non-compliance with the core obligations set out in paragraph 43 above, which are non-derogable. (\$47)

Now, $\$ 43$ confirms that State parties have an obligation ' ... to provide essential drugs, as from time to time defined under the WHO Action Programme on Essential Drugs' and 'to ensure equitable distribution of all health facilities, goods and services'. As drugs for an anti-retroviral therapy are on the World Health Organization (WHO) Essential Drugs List, states are formally obliged to provide this therapy to HIV/AIDS patients, but many sub-Saharan African states (with per capita public annual health expenditures of between US\$5 and US\$20) ${ }^{3}$ are certainly not in a position to fulfil such an obligation. States, however, also have the obligation to assist other states in fully realizing the right to health:

States parties should ensure that the right to health is given due attention in international agreements and, to that end, should consider the development of further legal instruments. In relation to the conclusion of other international agreements, States parties should take steps to ensure that these instruments do not adversely impact upon the right to health. Similarly, States parties have an obligation to ensure that their actions as members of international organisations take due account of the right to health. $(\$ 39)$

And, finally, $\$ 64$ reads:

Moreover, coordinated efforts for the realisation of the right to health should be maintained to enhance the interaction among all the actors concerned, including the various components of civil society. In conformity with articles 22 and 23 of the Covenant, WHO, the International Labour Organization, the United Nations Development Programme, UNICEF, the United Nations Population Fund, the World Bank, regional development banks, the International Monetary Fund, the World Trade Organization, and other relevant bodies within the United Nations system, should cooperate effectively with States parties, building on their respective expertise, in relation to the implementation of the right to health at the national level, with due respect to their individual mandates.

The 'right to health' is codified in slightly different formulations in a number of other international agreements. ${ }^{4}$ As such, it constitutes binding international 
law, but it is widely seen as a typical example of 'soft law', which corresponds to principles of basic human rights but is certainly also far from being an obligation enforceable by any institutionalized processes.

Indeed, it is difficult to develop a comprehensive concept on how the 'right to health' should be universally implemented. What we argue is that (1) states have an obligation to assist other states in fully realizing the right to health and to ensure as members of IGOs that those states 'take due account for the right to health' and, (2) international human rights law explicitly includes access to essential medicines into the core obligations of every state. Though 'access to essential medicines' only constitutes one aspect of the 'right to health', it nevertheless constitutes one issue by which to test the international community's readiness to implement social human rights. In fact, it is interesting to examine the extent to which pressure by civil society can substitute for the lack of material sanctions available to support the implementation of human rights.

In the following we examine the realization of these commitments in the context of globalization and in particular, in relation to access to HIV/AIDS drugs.

\section{Globalization, Actors in Health Politics and Governance}

The huge gap between the need for achieving a significant improvement of global health from a global rights as well as a global public goods perspective and the results attained within the system of international governmental institutions as it has developed after the Second World War, is certainly one of the factors that has led to the development of a new institutional structure in the Global Governance of Health. The reference to an increasingly complex structure of different types of actors in global health is commonplace (Dodgson et al., 2002; Hein and Kohlmorgen, 2003; Kickbusch, 2003; Lee et al., 2002).

Political globalization can be seen as an expression of a new configuration of actors, summarized by the term 'governance'. Governance includes regulation by state (nation states, intergovernmental organizations), by private regulation (private sector and civil society) and forms of hybrid regulation (cooperation between states/IGOs, private sector and/or civil society). Modifying a definition by Renate Mayntz (2005), we can speak of GHG as the totality of collective regulations to deal with international and transnational interdependence in the context of health issues (Bartsch and Kohlmorgen, 2005).

While the increased importance of non-state actors is a general characteristic of politics in the era of globalization, non-state actors, in many regards, play a more important role in the health sector than in other sectors. It can be claimed that there is hardly any other field of global politics where new institutional forms have gained comparable significance as in global public health particularly in relation to financing, as in the case of the Global Fund to Fight AIDS, Tuberculosis and Malaria and of the role of foundations in the financing of many of the Global Public-Private Partnerships in Health. One general 
reason for this can be seen in the historical tradition of non-state actors' involvement in health affairs (Loughlin and Berridge, 2002). Moreover, the role of new actors and institutions refers to the political weight of global civil society, which has become particularly present in the conflicts around the TRIPS agreement and the access to treatment for millions of HIV/AIDS patients. Human Rights organizations (CIEL, 3 D, Amnesty International), the Third World Network, Médecins Sans Frontières (MSF), and CP-Tech (now part of Knowledge Ecology International) as a crucial and comprehensive disseminator of information in all aspects related to intellectual property rights in health have played a crucial role in these conflicts (see also Ford, 2004). CSOs also were quite influential in shaping the outcome of the WHO-sponsored Commission on Intellectual Property Rights and Innovation in Health (CIPIH). The publication of the first alternative world health report (Global Health Watch, 2006) has created another venue of CSO influence. Another aspect has been the more recent particular prominence of non-traditional mechanisms to generate resources for ends otherwise obviously underfinanced: the development of an entire system of GPPPs and the mounting role of private foundations (in particular the Gates Foundation) and philanthropy in general are examples of such mechanisms where global health plays an important role (Kaul, 2006: 222; Micklewright and Wright, 2003: 15-16). In the following, we give a brief overview of the constellation of actors of GHG and introduce the main actors in terms of their changing roles in supporting global health.

The WHO was founded by the members of the international community 'for the purpose of co-operation among themselves and with others to promote and protect the health of all peoples' (WHO Constitution). Therefore, it is the organization of nation states to promote global health, and the delegates of member states decide on the organization's strategies and policies in the World Health Assembly. The WHO constitution declares that 'the enjoyment of the highest attainable standard of health is one of the fundamental rights of every human being'. 'Health for All' is not only the aim of WHO as an organization but it is also established as the central objective of international and national health activities by the nation states throughout the world. The International Conference on Primary Health Care in Alma Ata in 1978 proposed and the World Health Assembly in 1979 endorsed Primary Health Care as a strategy to achieve the objective of 'Health for All by the Year 2000', not just by giving the poor a minimum of health services (in a more liberal sense), but by providing health services for all as the foundation of a comprehensive health system (in a more universalistic sense).

The main responsibility for fulfilling this obligation lies with national governments, yet the IGOs and the world community are also committed to achieving a level of health for all people 'that will permit them to lead a socially and economically productive life' by the year 2000 (Declaration of Alma Ata 1978, WHO 1978). As we know, by 2000, the objective of 'Health 
for All' was not attained, and the likelihood of attaining it in the near future remains rather slim. Nevertheless, in 1998, WHO (to be precise: the World Health Assembly) renewed this objective under the label of 'Health for All in the 21 st Century'. This statement also proclaims that the availability of essentials of Primary Health Care should be ensured (Cueto, 2004; Thomas and Weber, 2004: 192ff.). Still, WHO had been severely hampered by a lack of internal flexibility to react to the new challenges of globalization and neoliberalism and a freeze of contributions to its budgets (Brown et al., 2006; Kohlmorgen, 2007; Lee, 2004; Yamey, 2002).

Although WHO should be the central organization of global health, the World Bank is the greatest single donor in health and one of the greatest single donors in the fight against HIV/AIDS, competing with WHO on conceptual issues of global health politics. The Bank can be characterized as an actor that chiefly aims at economic development (and thus only indirectly at the realization of global social rights). Besides health and HIV/AIDS programmes and loans, the Bank had (and still has) a great indirect impact on health policies due to the conditionality of structural adjustment policies that have now become poverty reduction strategies (Breman and Shelton, 2001).

The 1993 World Development Report 'Investing in Health' had an important conceptual influence on health system reforms in the 1990s: by recommending a public-private mix for financing the organization of health systems and insisting on contributions of patients to the cost of services, the Bank tried to link an expansion of social services to neoliberal economic concepts. Pushing new concepts on health systems with its extended lending activities in the background has made the bank a powerful player in the centre of GHG (Abasi, 1999; Buse and Gwin, 1998: 666; Lee et al., 1996; Thomas and Weber, 2004: 194).

As mentioned earlier, civil society organizations have for a long time played an important role in providing health care, in quite different forms - from religious orders to charity organizations. Foundations and professional organizations have been an important part of international health politics. During the 1990s, however, NGOs started to take a much more prominent position. CSOs combined the contestation of liberalization and the protests against increasing global inequality and a neglect of public responsibility in global social policies (to a large extent attributed to the Bretton Woods Institutions and WTO, see Khagram et al., 2002; O'Brien et al., 2000) with a high level of practical competence. Especially, some of the larger CSOs like Oxfam and Médecins Sans Frontières greatly increased their political weight in the fight for social rights interests in general and in the field of global health in particular (as expressed for example by awarding of the Nobel Peace Prize to MSF in 1999). They gained political influence, primarily in the discursive field (see Hein et al. 2007; Lee, 2003: 180-1; Zwi et al., 2002). While CSOs have been demanding more social justice in general, they succeeded in mobilizing support for specific issues such as access to medicines in the field of neglected diseases and HIV/AIDS. This again coincided with a turn of some large 
countries towards fighting specific diseases in which those actors saw the main threat to their own populations and politics. ${ }^{5}$

Moreover, pharmaceutical companies did their part in moving the focus of global health towards fighting specific diseases. They pursued their interests to maximize profits and to sustain and even to extend intellectual property rights as the main basis of refinancing their research and development (R \& D) costs. This created conflicts about the access of the poor to medicines against diseases by which they were most severely hit. Transnational pharmaceutical companies (TNPCs) tried to win support for their position by demonstrating corporate responsibility and becoming increasingly involved in partnerships aimed at improving the health situation of poor people basically through disease-specific activities (drug research, improving access) (see section four).

Finally, large foundations, particularly the Bill and Melinda Gates Foundation - due to their extensive resource-based power - entered the field with philanthropic aims. According to the Gates Foundation website, their total grant payments reached US\$1.56bn in 2006 (more than half of that in global health) and targets US\$3.5bn from 2009 onwards. Thus, the Gates Foundation has become one of the major funders for the promotion of global health. ${ }^{6}$

A certain decrease in the relative power of IGOs does not imply a similar decrease in the power of national governments, which in their aim to pursue their specific interests are trying to make use of the new constellations of global governance. This includes governments from developing countries allying themselves with CSOs as well as those from industrialized countries that again engage more forcefully in global health issues not only to pursue social or human rights interests but also self-interests like containing the risks of a global spread of infectious diseases and of political instability. In fact, the self-interest of rich countries may be one of the most important driving forces behind GHG.

Thus, the Global Fund to Fight HIV/AIDS, Tuberculosis and Malaria was established in 2002 with intense collaboration of the G8 countries and can be interpreted as a result of the mixture of these different interests. The Global Fund is a new form of hybrid regulation that seems characteristic for current structures of GHG. It is often regarded as a GPPP, which in a sense is true, but the fact that almost $96 \%$ of its funds are pledged by governments of nation states shows that it differs from 'typical' GPPPs (Bartsch, 2007; Bartsch and Hein, 2003). The Global Fund, currently the greatest single funding organization in the fight against HIV/AIDS, can be more precisely characterized as a multilateral funding mechanism that works like a partnership. It has a new and - compared with IGOs - unconventional governance structure: nation states (eight from the North, seven from the South), CSOs (three), foundations (one) and companies (one) are voting members of the Executive Board. WHO, World Bank and UNAIDS are only non-voting members. Recipient countries have to create a Country Coordinating Mechanism with the participation of all stakeholders (including civil society and private sector) that is authorized to apply for funds to conduct programmes. 
In 1995, the UN organizations involved in the fight against HIV/AIDS reacted towards the increasing perception of the pandemic as a threat to global health and social development with the establishment of the Joint United Nations Programme on HIV/AIDS (UNAIDS), as a new form of cooperative organization within the UN system. The main objectives of UNAIDS are to coordinate UN activities and to advocate a global reaction towards HIV/AIDS. Ten UN organizations and programmes are co-sponsors of UNAIDS, among them the United Nations Children's Fund (UNICEF), WHO, the World Bank, the United Nations Development Programme (UNDP), the United Nations Educational, Scientific and Cultural Organization (UNESCO) and the International Labour Organisation (ILO). Delegates of CSOs and of groups of people living with HIV/AIDS are non-voting members of the Programme Coordinating Board, the most important decision-making body of UNAIDS. UNAIDS, however, did not succeed in regaining the initiative in the fight against the disease (Kohlmorgen, 2007).

The focus of many of the new actors in GHG in fact seems to reflect the increased strength of health-related issues in global politics. However, they also reflect a change in focus of global health politics from primary health care to fighting diseases. 'Health for all' frequently appears to be equivalent to 'fighting the diseases of the poor'. Though this is certainly a questionable tendency, it appears to be closely related to two other very salient problems, which define necessary, though not sufficient, conditions to realize the universal right to health and which we will discuss in the following sections: (1) the access to medicines under the conditions of the internationalization of intellectual property rights through TRIPS and (2) the mobilization of resources, which appears to be easier when the concerns are concrete, easyto-understand scandals and not seemingly insurmountable barriers, such as bad living conditions and poverty in large parts of the South.

\section{TRIPS, Global Civil Society and Social Rights}

In the second half of the 1990s, drugs were available (and widely used in industrialized countries) that transformed HIV/AIDS into a chronic disease. A combination therapy consisting of three different anti-retroviral drugs allowed most AIDS patients to lead a relatively normal life - provided they did not develop resistances or strong side effects against these drugs and they (or their health insurance or national health system) were ready to pay about US\$10,400 per year for the drugs alone (MSF, 2005: 10). These expenses were not due to the production costs of the drugs but due to the exploitation of patent rights by pharmaceutical companies now internationalized due to TRIPS. Meanwhile, in certain countries, companies could (legally) produce the same drugs as generics for a fraction of these costs. ${ }^{7}$ For the first time we encountered a situation where effective forms of treatment were now available for a disease that had been at 
the centre of global attention for some time. These effective forms of treatment were available in general but not accessible for the majority of people in need of them due to a lack of resources or extremely high prices. The moral argument for allowing poor people access to medication as well as the political importance of fighting the HIV/AIDS pandemic in poor regions could not be denied. The fact that some countries - like India - could offer cheaper drugs due to specific circumstances made the situation even more untenable.

The WTO's objective is to regulate and facilitate world trade, it is not a welfare-oriented (or multipurpose) organization. Nevertheless, free trade has always been promoted with the promise that it will create a win-win situation for all participants. Thus, in a number of ways, it is normatively related to global welfare: the WTO is based on the general assumption that expanding trade has a generally positive impact on welfare. The preamble to the Agreement Establishing the World Trade Organization includes goals supporting 'development' and improving standards of living. ${ }^{8}$ In addition, safeguard mechanisms can be used in situations of social crisis, and specific WTO committees deal with welfare-related problems. We find more concrete references to public health in Art. 8,1 of the TRIPS agreement:

Members may, in formulating or amending their laws and regulations, adopt measures necessary to protect public health and nutrition, and to promote the public interest in sectors of vital importance to their socio-economic and technological development, provided that such measures are consistent with the provisions of this Agreement.

Similar references can be found in various other agreements. ${ }^{9}$ Certainly, the interpretation of these references is limited by the general aims of the agreements of which they form a part (i.e. liberalization of international economic relations), but they constitute normative points of reference that can serve as a starting point for interpreting and readjusting provisions of the agreements depending, of course, on relations of interests and power in global politics. The defence of agricultural protectionism in the context of WTO is proof of the central role of power relations in the concrete working of the agreements. The conflicts on the interpretation and amendment of TRIPS between 1997 and 2005 are a further demonstration of these power relations.

These conflicts have been analysed in detail by various authors. ${ }^{10}$ They played an important role in a research project on GHG, in which the authors participated and carried out 36 interviews with representatives of international organizations and CSOs in Geneva - here we refer to the most important steps of this process.

First, in the late 1990s there were conflicts about the interpretation of TRIPS between the Brazilian and South African governments on the one side and TNPCs and the US government on the other. Both countries were not as fortunate as India: India's patent law of 1970 (enacted in 1972) did not provide product patent protection and - according to Art. 65.4-TRIPS allowed 
it ten years to adjust the law to TRIPS rules (see also Chaudhuri, 2005: 63). Brazil and South Africa had to make their patent laws compatible with TRIPS by 2000 and did so by 1997 . Brazil basically tried to put pressure on pharmaceutical companies to reach better terms of access to antiretrovivals (ARVs) and to reduce the prices of drugs in Brazil in order to finance the national programme for ARV treatment to all those in need (Wade, 2003: 5ff.; Wogart and Calcagnotto, 2006). In South Africa, the Pharmaceutical Manufacturers' Association, backed by 39 Pharma TNCs, filed a lawsuit against the South African Government in 1997, which in that year had authorized the health department to determine the conditions under which parallel imports to lower the costs of AIDS treatment should be permitted (Medicines and Related Substances Control Amendment Act). The lawsuit was first dropped in late 1998, then reinstated in January 2001 and finally withdrawn in April 2001 , as it proved to be detrimental to the image of the pharmaceutical industry (see Kühl, 2002; Lanoszka, 2003; Weissman, 2001).

Second, with pressure by the African Group in WTO and support by documents accepted shortly before by WHO and the United Nations Conference on Trade and Development (UNCTAD) (Correa, 2002), the so-called Doha Declaration on the TRIPS Agreement and Public Health was adopted during the 4th Ministerial Conference of WTO at Doha in November 2001, stating:

... that the Agreement can and should be interpreted and implemented in a manner supportive of WTO members' right to protect public health and, in particular, to promote access to medicines for all. In this connection, we reaffirm the right of WTO members to use, to the full, the provisions in the TRIPS Agreement, which provide flexibility for this purpose $(\$ 4$, referring to the possible use of compulsory licenses and parallel importing).

Third, $\$ 6$ of the Doha Declaration stipulated further negotiations on the conditions of compulsory licenses for the supply from third party countries, as compulsory licensing was authorized basically for local consumption, posing a problem for countries having no industry to produce generic versions of needed drugs. Again, after one and a half years of negotiations, the industry (basically represented by US negotiators) had to accept the authorization of compulsory licensing for import irrespective of the disease involved. ${ }^{11}$ On the other hand, developing countries had to accept what they see as burdensome requirements: the obligation of producers to mark these products by a specific shape, colour or packaging and the requirement of notification on the lack of local technological capacities. Later we will take up this argument again.

Fourth, the TRIPS Amendment ( $\$ 31 \mathrm{f}$ and $\mathrm{h}$ ) of December 2005 finally took over the $\$ 6$ decision; CSOs and developing countries did not succeed in reducing requirements for compulsory licensing, like the requirements referred to above and the Chairpersons' statement, which lists the countries that have opted out of using the system as importers (WTO General Council, WT/GC/M/82, 13 November 2003). Thus, after the 2005 amendment many 
NGOs might uphold their critique that the $\$ 6$ decision is really 'unworkable' (Abbott, 2005: 317), but on the other hand, studies show that the use of TRIPS flexibilities as confirmed in this process might in fact help to ensure a sustainable supply of essential medicines in sub-Saharan African countries (Avafia et al., 2006).

The (intermediate) result of the conflict led to a situation where the position of the WTO Secretariat approached that of civil society groups often seen as 'globalization critics', while the pharmaceutical industry only grudgingly accepted the results. At the same time TNPCs turned to other paths to realize their aims, like bilateral trade agreements. Particularly since the Brazilian HIV/AIDS programme received international praise for its success in providing general treatment and in order to pressure TNPCs to offer drugs at affordable prices, public opinion had become mobilized against politics of intellectual property rights that guaranteed profits to TNCs while effectively denying treatment to those in need. Obviously, at least under strong observation by the media, political leaders might be effectively put under pressure not to concede a limitation of TRIPS flexibilities because of the interests of private economic actors (see Abbott, 2005: 356).

Brazil and South Africa played a crucial role in mobilizing a global public to take seriously the welfare-related clauses in the TRIPS Agreement (as expressed in Articles 7 and 8). This success, however, depended on the active role of a global civil society, taking up these demands and channelling them into pressure on rich country governments. The strength of CSOs in GHG can be seen as a result of a twofold strategy of both protesting/lobbying and providing knowledge/cooperation. While CSOs organized pressure on Northern states by essentially influencing public opinion, they also more or less directly influenced and coordinated the political positions of smaller Southern nation states, which otherwise would have hardly had any impact on WTO negotiations. CSOs worked as advisors to developing country members of WTO and thus empowered poor developing countries to take a strong position in the negotiations on $\$ 6$. In doing so, CSOs assumed an important role as 'midwives' for the development of formal global politics. ${ }^{12}$

However limited, the Doha Declaration and the $\$ 6$ negotiations demonstrate that - at least under certain conditions - it is possible to convert the safeguards and general clauses included in the WTO agreements into concrete compromises to deal with situations of obvious injustice. Certainly, this must be seen as part of a process of global socialization: a market-based global economic integration is only sustainable if it is supplemented by institutional developments that can deal with the social inequalities and conflicts, i.e. if it permits the articulation between traditional and new social actors in new processes of shaping global rules and finding compromises to solve conflicts. Though critics of the $\$ 6$ solution point to the fact this mechanism has not been used by countries concerned, there can be no doubt that the negotiating position of these countries has been strengthened. ${ }^{13}$ Thailand issued a compulsory licence for ARVs produced by Abbott, Merck and 
Sanofi-Aventis in January and February 2007 and Brazil took a similar step in May 2007. They did not need to use the proposed solution. It thus remains to be seen whether this mechanism will work to ease access to medication in the case of other diseases or in the case of new generations of AIDS medicines. The Indian patent law introduced in 2005 will not prohibit the ongoing generic production of firstline ARVs (Abbott, 2006: 6; Chaudhuri, 2005: 65-70). For patients who need second-line ARVs because of resistance and medical incompatibilities, the only relatively low-priced drug (lopinavir/ritonavir from Abbott Laboratories) is available only in least developed countries at the reduced price of US\$550, while it is sold in low middle-income countries like El Salvador and Peru for between US\$4468 and US\$4511 (Vasan et al., 2006: 395). Moreover, there is an urgent need for cheap drugs specifically suitable for the treatment of children. According to MSF, a treatment with the usual triple combination in a paediatric formulation for a child weighing $10 \mathrm{~kg}$ can cost US\$816, while treating an adult costs only US\$182 (MSF, 2005: 4ff.). Thus, issues for new conflicts lie ahead.

\section{Pharma TNCs and GPPPs: Accepting the Right to Health and Defending Corporate Interests}

Intellectual property rights are the most important basis for recovering the capital invested by pharmaceutical companies in R \& D. A widely quoted estimate of US $\$ 802 \mathrm{~m}$ for the development costs of a new medicine is based on a US research project. ${ }^{14}$ The appropriateness of assumptions made in this project have been questioned and there seems ground to assume that in many cases costs are considerably lower. The TB Alliance for example arrived at estimates between US\$115m and US\$240m for each tuberculosis drug (CIPIH/WHO, 2006: 75-6). However, in comparison to many other industries, there is little doubt about the dimension of costs and risks involved. Therefore, it is not surprising that the industry is strongly opposed to any form of weakening the patent system even if they might concede that this system has its flaws - and that they are fiercely lobbying governments, in particular the US government, to support TRIPS and the Intellectual Property Right (IPR) system (see for example Braithwaite and Drahos, 2000: 58-87).

Bilateral Free Trade Agreements (FTAs) have been used by the US government to incorporate clauses that forced trade partners to exclude the possibility of using the flexibilities included in TRIPS. Most partners agreed to these demands as their priorities were oriented towards getting access to the US markets for their export industries. ${ }^{15}$ Frederick Abbott writes of a TRIPS II agenda of 'strong mercantile interests' ${ }^{16}$ seeking to increase technology and 'expression rents' 17 in reaction to the change of conditions following the negotiation of the TRIPS Agreement in the course of the Uruguay Round (Abbott, 2006). These problems had been discussed at length with regard to different US trade agreements with Latin American countries and Thailand. ${ }^{18}$ 
On the other hand, the more the right to health is becoming a central political and moral issue, the more the industry is coming under pressure to live up to its corporate responsibility and contribute to the struggle for a 'better health for all'. In fact, from their perspective, nothing appears better suited than a strategy of GPPPs. ${ }^{19}$ In the first instance, GPPPs evolved since the end of the 1980 s as a result of the problems faced in developing new medicines and vaccines for the typical diseases of the poor and marginalized parts of the global population, which had been neglected because there were no opportunities for TNPCs to recover drug development costs on the market. Through the cooperation between relevant actors, usually IGOs (frequently WHO), pharmaceutical companies and occasionally private sponsors, costs and risks in R \& D are shared and the access of poor people to the new drugs is guaranteed. ${ }^{20}$

Another type of GPPP concentrates on easing access to drugs that are already on the market, such as the Mectizan Donation Programme (medicine against river blindness and elephantiasis) (Frost and Reich, 1998). The most important programme in the case of HIV/AIDS is the Accelerating Access Initiative (AAI, cf. Sturchio, 2004). This is a GPPP involving five UN agencies (UNAIDS, WHO, World Bank, UNICEF und UNFPA) and seven pharmaceutical companies (Abbott Laboratories, Boehringer Ingelheim, BristolMyers Squibb, GSK, Gilead Sciences, Merck Co. and Hoffmann-LaRoche), working together with national governments in providing access to HIV-treatment. An International Federation of Pharmaceutical Manufacturers \& Associations (IFPMA) document published in January 2005 highlighted that by September 2004, 330,000 patients were treated with ARVs supplied by AAI companies, i.e. about half of all patients in developing countries receiving treatment at that time (IFPMA, 2005).

Many of the GPPPs have been criticized by civil society actors and often by public health specialists as well for linking humanitarian actions to specific interests of the firms involved such as generating PR material and not offering reliable and transparent solutions to the problem of access and medical service (Buse and Lee, 2005; Buse and Walt, 2002; Health Action International, 2001; Richter, 2003, 2004). On the other hand, there is no doubt that the rise of GPPPs reflects the acceptance that pharmaceutical R \& D and the access to patented drugs are a public issue that needs to be negotiated. The role of GPPPs fits into the general picture of an increasing complexity of GHG: though it is difficult to assess 'how these initiatives affect the health and the conditions of those they are meant to help' (Health Action International, 2001), they have constituted another field of activity characterized by a broad involvement of various types of actors in GHG thus strengthening the general acceptance of a universal right to health.

Other instruments that are accepted by the pharmaceutical industry are differential pricing, ${ }^{21}$ and so-called Advance Purchase Schemes, i.e. public assurances (and prepayments) to purchase medicines on which research is done, providing inventors with some guarantee regarding the income they can expect. 


\section{Mobilization of Resources for Fighting HIVIAIDS: Old and New Actors in Global Health Governance}

The availability of generic ARVs offered mainly by Indian producers, negotiations of the Clinton Foundation, the World Bank, UNICEF and the Global Fund with these generic producers in India for special prices in bulk purchases, the improved negotiating position of developing countries due to the Doha Declaration and the TRIPS Amendments and, finally, concessions by TNPCs themselves have led to a dramatic fall of ARV prices in developing countries. Since the late 1990s they fell from well over US $\$ 10,000$ to about US\$140 (for generics, per person/year, in some countries) in 2005 (MSF, 2005: 10). Hence we now have a situation in which the transfer of international resources in many poor countries could at least open a window for starting treatment programmes on a larger scale. Indeed, according to UNAIDS, from 1996 to 2005 the money spent on the global fight against HIV/AIDS in low- and middle-income countries increased from US $\$ 300 \mathrm{~m}$ to US $\$ 8.3 \mathrm{bn}$ altogether (including national and international funding). However, as raising US\$140 per year is still a problem for many AIDS victims in poor countries and a proper health system is indispensable for the functioning of AIDS treatment, more funding is necessary. UNAIDS states that there is an increasing funding gap to reverse the global HIV/AIDS pandemic. For 2007, for example, about US\$18bn is needed, but only US\$10bn is expected to be available (UNAIDS, 2006: 224-5).

Will the new institutional setting in GHG also help to mobilize sufficient resources to implement at least the social rights to treatment in the case of people living with HIV/AIDS? A brief look at the funding of global health activities shows that state actors are still at the centre of governance structures. 'New' institutional modes of governance and 'new' actors are only to a limited degree the source of increased funding, even if their pressure might play an important role to mobilize these resources. In 2005, governments of the OECD/DAC (Development Assistance Committee) countries provided US\$5.1bn for HIV/AIDS (through bilateral and multilateral commitments). Domestic sources within low- and middle-income countries amounted to US\$2.8bn, and private sources contributed only about US\$0.4bn (UNAIDS, 2006: $231 \mathrm{ff}$.). Furthermore, it is noteworthy that in 2005 G8/EU governments disbursed - despite the existence of the Global Fund - US $\$ 3.5 \mathrm{bn}$ through bilateral programmes, whereas only about US $\$ 0.81$ bn were allocated via the Global Fund (Kates and Lief, 2006: 9). Thus, the G8 countries are the major players in terms of funding and - as providing resources generally translates into influence and power - also in terms of policies and strategies of GHG. Since the G7/G8 summit in Okinawa in 2000, the G8 addressed infectious diseases, and particularly HIV/AIDS, as a major problem to human security and included the fight against HIV/AIDS in poverty reduction strategies. 
Despite all bilateral activities, the G8 countries together with Kofi Annan initiated the Global Fund. The Global Fund has attracted pledges of US\$9.5bn until 2008 and approved US\$5.6bn to support programmes in 132 countries thus far (September 2006). ${ }^{22}$ Of the money donated, $94.4 \%$ is provided by OECD members, $1.1 \%$ by non-OECD countries. A closer look at the $4.5 \%$ private and civil society donations shows that the Bill and Melinda Gates Foundation - generally one of the largest funders of global health activities alone is responsible for $97 \%$ of all non-state donations. Corporations contributed only $0.06 \%$ of all donations. ${ }^{23}$ Thus, the Global Fund hardly generates any financial resources from new and unconventional sources.

The Global Fund was launched as a finance mechanism separate from the UN system because the USA, in particular, but also Japan and Italy did not want to have it under the auspices of the UN. This, of course, led to controversial discussions, because UN organizations, and especially WHO, feared a loss of influence on global health issues and some health experts and CSOs were afraid of a privatization of governance. ${ }^{24}$ This separate construction of the Global Fund is an interesting point when considering the interests and strategies of powerful nation states: nation states (in this case mainly the USA) use hybrid regulation (the Global Fund) to circumvent formally legitimized IGOs (WHO and World Bank) in allocating money to fulfil a global public task. This means that hybrid regulation and networks, which lead to a sharing of the states' power and influence with other actors, are a result of interests of nations states. Yet at the same time, the partnership structure of the Fund involves actors fighting for social rights, like CSOs and also organizations of people living with HIV/AIDS, and facilitates a bottom-up approach in the process of fund application, which empowers actors at the national and local level. Including actors that have long been involved in the fight against HIV/AIDS, tuberculosis or malaria as well as experts, while trying to prevent group-oriented (industrialized vs. developing countries) political alignments makes sense in principle - whether it will solve problems more effectively is another question.

As a funding agency, the Global Fund competes with the World Bank, which, as already mentioned, is the greatest single donor in health and one of the greatest single donors in the fight against HIV/AIDS. Since 2000, the World Bank runs the Multi-Country HIV/AIDS Program (MAP). Together, 26 African countries have received more than US\$1bn so far. ${ }^{25}$ Although the US government has considerable influence on the Bank's policies and strategies and although it played an important role in the establishment of the Global Fund, it launched the President's Emergency Plan for AIDS Relief (PEPFAR) as a bilateral programme (or better: a global unilateral programme) in 2004. PEPFAR will provide US\$15bn to fight HIV/AIDS until 2009 (US\$9bn for new bilateral programmes in 14 African and Caribbean countries, US\$5 bn for existing programmes in 75 countries and US\$1bn for the Global Fund). It is implemented mainly by USAID, but with substantial involvement of some US-based CSOs and certain CSOs from the recipient countries, mainly 
faith-based organizations (Bartsch and Kohlmorgen, 2007). PEPFAR propagates the $\mathrm{ABC}$ method of AIDS prevention: $a$ bstinence, $b$ eing faithful in partner relationships and using condoms, with the emphasis on ' $\mathrm{A}$ ' and ' $\mathrm{B}$ ', with ' $\mathrm{C}$ ' only as a last solution or for risk-groups (such as prostitutes). Besides prevention, PEPFAR also focuses on treatment. After CSOs accused the Office of the US Global AIDS Coordinator (which until 2006 was led by Randall L. Tobias, a former CEO of the pharmaceutical company Eli Lilly \& Co.) of only financing branded drugs, PEPFAR now also utilizes generic drugs in its programmes (in 2006: $27 \%$ of total procurement of ARVs; see Office of the US Global AIDS Coordinator, 2007: 70).

The fact that PEPFAR is primarily a bilateral programme and does not allocate greater financial resources to multilateral funds indicates that the US government preferred to develop a programme that it could control according to national interests, while at the same time attaching a great deal of importance to the fight against HIV/AIDS. Due to a general scepticism towards multilateralism and due to specific interests of social groups in the USA, the activities of WHO, UNAIDS and also the Global Fund are increasingly circumvented. We can identify - besides the general attitude of unilateralism - a rather strange mixture of interests affecting the way the US government conducts PEPFAR, such as interests of pharmaceutical companies, Christian beliefs and conservative opinions. The general impetus to fund the fight against HIV/AIDS may arise from interests in presenting the USA not only as a warfaring nation but also as a soft power that assumes responsibility for global problems like poverty and infectious diseases, but also has interests in the political stability of focus countries, which partly have important strategic positions in conflict-ridden regions and/or have natural resources (Burkhalter, 2004; Ingram, 2005; Morrison, 2006). Although this concerns basically national selfinterests (or collective interests of rich countries), it can improve the likelihood of realizing social rights in the countries concerned. PEPFAR, born out of national interests, is a contribution to GHG and promotes the establishment of global social rights.

Looking at WHO as an actor in GHG and taking into account the development of additional forms of funding from many organizations, particularly those from the global civil society that have become involved in global health discourses, one can argue that WHO is, especially since the 1990s, a relatively enervated actor of GHG, particularly in the fight against HIV/AIDS. This is related to the aforementioned complicated decision-making processes that have to aggregate the interests and commitments of member states and is therefore linked to bureaucratic forms of organization. In addition, other factors weakened WHO's position until the turn of the Millennium: incoherence between voting-power (majority position of developing countries) and the control of financial resources (resistance by, against many industrialized countries an increase of the ordinary WHO budget); limited resource-based power of WHO not being a funding organization (primarily knowledge and advisory 
capacities) and, finally, competition by new actors in the field of GHG became stronger. During the last years, however, WHO has used various new strategies to regain the initiative in GHG.

Two of these strategies can be identified in the field of infectious diseases. The first - under the aegis of Gro Harlem Brundtland - has been to enhance PPPs (e.g. Stop TB and Roll Back Malaria are hosted by WHO). These efforts can be interpreted as a reaction of WHO to the changed institutional setting and as an attempt to regain the initiative in this institutional context, which provides private actors with greater influence in politics. The second strategic decision was the reintegration of the fight against HIV/AIDS into WHO. After the establishment of UNAIDS in 1996, WHO transferred its competencies, personnel and resources in this field to this new joint venture of UN organizations. In spite of major problems in coordinating the UN member organizations, UNAIDS can be seen as the leading UN organization in the fight against HIV/AIDS as far as normative and strategic aspects are concerned, that is until WHO started to develop its own HIV/AIDS policy again in 2000-1. In 2003, WHO (together with UNAIDS) launched the so-called 3 by 5 Initiative, which aimed at providing $3 \mathrm{~m}$ people suffering from AIDS with ARV drugs until the end of 2005.

Consistent with our hypothesis about the essentially positive impact of the new institutional configuration on the implementation of social rights, we can observe that networks were crucial in the pursuit of the objectives of 3 by 5 . Due to its lack of funds, WHO could only increase its budget for more activities in training health workers and developing health systems, but could not close the estimated 3 by 5 funding gap of US $\$ 5.5 \mathrm{bn}$. WHO cooperated with all the other organizations and initiatives in the GHG field. However, with the 3 by 5 Initiative, WHO tried to strengthen its own position and attempted to gain influence in the global HIV/AIDS politics arena and in one of its most salient policy fields, AIDS treatment. Though the goals of the initiative were not reached (only $1 \mathrm{~m}$ patients on ARV treatment by August 2006; WHO, 2006), WHO continued its strategy on the same line with its target of 'Universal Access by 2010'.

Finally, WHO tried successfully to strengthen its position by taking over a role as an initiator of new discourses. This started with the Commission on Macroeconomics and Health (CMH; 2000-2) and was carried on in 2004-6 with the Commission on Intellectual Property Rights and Innovation in Public Health (CIPIH) and the work of the Commission on the Social Determinants of Health since 2005. CIPIH together with the proposed resolution on a Global Framework on Essential Health Research lead to the establishment of an Intergovernmental Working Group on Public Health, Innovation and Intellectual Property Rights.

This points to another political field in which $\mathrm{WHO}$ as an intergovernmental organization has asserted its role, the negotiations of international agreements. The new International Health Regulations, which coordinate restrictions on travel and the exchange of goods, cooperation in surveillance 
and research in international health emergencies (Fidler, 2005), and the Framework Convention on Tobacco Control (Collin et al., 2005) are generally seen as important achievements.

The activities in the fight against HIV/AIDS exemplify some of the contradictions and inconsistencies of the institutional modes of global governance: on the one hand, powerful nations shifted their activities to the Global Fund (to bypass WHO), which implies a sharing of power with other actors, while on the other hand, they pursued their own interests by conducting bilateral programmes such as PEPFAR. Meanwhile, the Global Fund itself is sidestepped and has difficulties in attracting enough funding. Although it is quite normal that donor countries disburse most of their money via bilateral programmes - as this allows them best to pursue their interests - it is striking that the US government, for example, established PEPFAR after playing a crucial role in creating the Global Fund. This can be characterized as forum shifting from a multilateral network, e.g. with at least some aspects of a bottom-up approach, to a hierarchical state institution with a top-down approach. However, both PEPFAR and the US contributions to the Global Fund demonstrate that powerful and rich nation states are willing to make compromises at the global level in order to tackle global problems. Nevertheless, at the same time, nation states remain powerful actors and they can use the institutional context of these compromises, the partnerships and networks, to pursue their interests. In spite of the games played by powerful actors in solving problems through cooperation while trying to keep as much control as possible, the institutional and political compromises and the mixture of human rights interests and national self-interests seem to increase the political efforts and financial resources to tackle health problems in developing countries. This contributes, at least in one field, to the realization of social rights at the global level.

\section{Conclusion: Current Form of Global Heath Governance as a Patchwork of Compromises}

We started our analysis of conflicts on social rights in the field of global health by explaining the commitments on social rights and especially on rights to health made by the global community. Due to the hegemony of neoliberal concepts in economic globalization during the 1980s and early 1990s, progress in the realization of social rights was slow in most developing countries as priority was given to economic liberalization and political freedom. Since the mid1990s, insights have gained ground that poverty reduction and improvements in health do not automatically result from liberalization and economic growth, and that parts of the global economy are marginalized or even excluded from trade and foreign investments (especially parts of Africa). Today, poverty reduction and greater efforts to fight infectious diseases like HIV/AIDS are among the top issues of the global political agenda to mitigate the biggest social problems resulting from economic liberalization. 
At the same time, the globalization process has intensified the density of social and political interactions on a global scale. We face an increasing global awareness of conflicts and social problems. Richer countries realize that problems in marginalized regions are also to some extent their problems, as for example in the case of infectious diseases or HIV/AIDS threatening the economic and political stability in some countries and regions that might in turn have international consequences. As the global risks of infectious diseases and the importance of health to social and political stability are acknowledged, health is increasingly perceived as a global public good that requires strengthened global efforts. Thus, the increasing global awareness of problems and the global activities to tackle these issues are related to the self-interest of well-to-do people in the North.

Moreover, the global political space has become increasingly important. Due to a lack of adequate reactions of nation states and IGOs to these global problems, civil society and private sector actors play a prominent role in the evolving global governance - particularly in social and health policy affairs. This has a twofold effect. On the one hand, corporations and business associations use this political space to pursue their interests and to foster market liberalization that might undermine social rights. On the other hand, actors like NGOs, advocacy groups and foundations that strengthen social rights have a greater influence on politics - and are putting pressure on large enterprises to assume corporate responsibility.

Of course, we are a far cry from implementing the whole body of social rights laid down in the International Covenant on Economic, Social and Cultural Rights. Nevertheless, we can observe increasing efforts to realize social rights in the field of health based on the moral power of advocacy and the changing pattern of material interests in the course of the integration of global society. The analysis has shown that the current forms and effects of GHG are characterized by institutional and political compromises. The Doha Declaration, and the $\$ 6$ decision in particular, can be seen as such a compromise. In addition, the establishment of the Global Fund represents a political and institutional compromise between actors pursuing material interests, such as containing health risks and reaching social and political stability (governments of industrialized countries) and securing profits (pharmaceutical companies) on the one hand, and actors striving for social rights on the other.

Part of the current structure of compromises is the bypassing of the formally legitimized UN organizations such as WHO. Powerful actors, i.e. governments from nation states, use hybrid regulation and networks to achieve their goals. However, at the same time, the engagement in networks means being compelled to make compromises. WHO-at least formally the central organization of GHG and the central global entity to provide and guarantee social rights in the field of global health - is to some extent weakened due to strategies of forum shifting of governments from the North. It has the structural problem of not being a funding organization. Its power is based on its 
legitimacy as a global organization representing member states, on knowledge and the capacities to set norms.

The new institutional setting of GHG based on networks, partnerships and increased private activities strengthens social rights to health for victims of diseases: the basic right to live at all. However, it does not - at least at the moment aim at comprehensive social rights in the field of health, which would require the improvement of general living conditions (access to healthy food, clean water and sanitation) and well-developed health systems. Moreover, we can maintain that the current primary focus of GHG on specific diseases is, in various aspects, contradictory to the realization of this basic social right for all, as it is only a selective strategy. It remains to be seen whether the current compromises can function as basis for future politics targeting social rights for all.

In our analysis we have observed the integration of a progressively complex political field of GHG characterized by its relationship to soft and hard international law, institutional arenas of conflicts, channels of financial transfers and manifold old and new actors linking this political field ever more closely to increasingly dense global social structures. There is no reason to expect a harmonious collaboration of these actors to promote rights to health, but there is reason to expect that these rights (and that means, above all, the health of the poor) are becoming a much more significant global political issue than it was some decades ago. Drawing a conclusion from this particular issue for the wider field of global social policy we can say that the evolving structures of global governance have some potential to effect greater global social justice and cohesion. However, this process is still in its infancy, and the level of social rights improvement reached thus far is not stable as governance structures remain fragile and fragmented.

NOTES

1. 'Densification' refers to the definition of globalization given in Held et al. (1999: 16): 'a process ... which embodies a transformation in the spatial organization of social relations and transactions - assessed in terms of their extensity, intensity, velocity and impact - generating transcontinental of interregional flows and networks of activity, interaction, and the exercise of power'. These tendencies towards an increased interconnectedness and interdependence or global social relations constitutes a basis for talking about an evolving global society.

2. This document is part of a series of comments by the CESCR called 'Substantive issues arising in the implementation of the International Covenant on Economic, Social and Cultural Rights' adopted since 1989, here 'General Comment No. 14' (document E/C.12/2000/4), accessed 12 December 2007, http://www.bayelsty. com/themes/health-general-general-comments.php.

3. cf. WHO website, accessed 25 April 2007, http://www.who.int/countries/en/

4. In addition to the International Covenant on Economic, Social and Cultural Rights, see the Convention on the Elimination of All Forms of Discrimination Against Women (Articles 10, 12 and 14), the Convention on the Elimination of All Forms 
of Racial Discrimination (Art. 5) and the Convention on the Rights of the Child (Art. 24). In addition, Art. 35 of the Charter of Fundamental Rights of the European Union refers to the rights established by 'national laws and practices' and adds that: 'A high level of human health protection shall be ensured in the definition and implementation of all Union policies and activities.' Furthermore, we find commitments by governments to improve human health in a number of declarations and Programmes of Action (Agenda 21, chapter 6, \$\$ 1 and 12; Cairo Programme of Action, Principle 8 and $\$ 8.6$; Copenhagen Declaration, Commitment 6; Beijing Declaration, $\$ \$ 17$ and 30; Habitat Agenda $\$ \$ 36$ and 128) and, of course, in the Millennium Declaration.

5. For a more detailed analysis on the development of global civil society and its relation to health, cf. Bartsch and Kohlmorgen (2007) as well as Hein (2007).

6. For the data see http://www.gatesfoundation.org/MediaCenter/FactSheet/ (grant payments in 2006) and http://www.gatesfoundation.org/AboutUs/RelatedInfo/ Buffett.htm (2009 target), accessed 21 June 2007.

7. This was due to the provision of the TRIPS agreement that developing countries, which had already enacted their own system of patent protection did not have to adjust them to TRIPS rules until 2005, which was the case for India.

8. 'The Parties to this Agreement, Recognizing that their relations in the field of trade and economic endeavour should be conducted with a view to raising standards of living, ensuring full employment and a large and steadily growing volume of real income and effective demand, and expanding the production of and trade in goods and services'.

9. For example, cf. GATS, Art. 14 b; preambles of the Agreements on Agriculture and on the Application of Sanitary and Phytosanitary Measures.

10. See for example the studies by Abbott (2005, 2006); Koivusalo (2003); Schultz and Walker (2005); Sell (2002); Sell and Prakash (2002) 't Hoen (2002); The authors' interviews are analysed in more detail in Hein (2007: 59-61) and Kohlmorgen (2007).

11. Finally, it has been agreed that it is up to the governments concerned to make use of the system established in the decision (except for those countries that have stated that they will use it only in a limited way or not at all).

12. In this context, the South Centre has played an important role in organizing communication between health NGOs and Southern national delegates to the WTO (interviews of the authors, see earlier).

13. Concerning the Thai CL on efavirenz (produced by Merck), in fact Merck now offers the medicine at a price competitive with a generic version produced in India if the CL would be revoked (ip-health, 4 June 2007). In mid-June 2007 there was still no definite decision from the Thai government.

14. DiMasi et al. (2003) analysed the R \& D costs for 68 randomly chosen drugs (of course, on the basis of data provided by the pharmaceutical industry).

15. Agreements are in force or signed with Jordan, Singapore, Chile, the countries of the Central American Free Trade Area, Australia, Morocco, Bahrain, Oman, Peru and Colombia, and negotiations are underway with the Southern African Customs Union and Thailand (see Abbott, 2006: 8).

16. This concerns the copyright-dependent audio-visual industry and the pharmaceutical and agricultural chemical industry.

17. 'Expression rents': rents based on licenses.

18. There are a number of critical texts on Free Trade Agreements with TRIPS+ provisions. The UNCTAD-ICTSD Project on IPRs and Sustainable Development 
has presented a number of interesting studies on these negotiations (see http://www.iprsonline.org/resources/FTAs.htm, accessed 25 April 2007); Oxfam produced various briefing notes and briefing papers on this subject (see Oxfam, 2002; see also Abbott, 2006; Vivas-Eugui, 2003).

19. Currently, there are about 80 GPPPs in the health sector (Bartsch, 2003; Buse and Walt, 2002; Richter, 2004; Widdus, 2001).

20. Examples of such GPPPs are the Medicines for Malaria Venture, the Global Alliance for TB Drug Development, the International AIDS Vaccine Initiative and the Global Alliance on Vaccines and Immunization.

21. Though an EU initiative in 2002 to register pharmaceutical companies offering price cuts of $80 \%$ or a price $10 \%$ above production costs for ARVs sold to least developed and other low-income countries (The Pulse. Health and Pharma Quarterly Check-up, Nov. 2002: 5-6) did not turn out particularly successful, pharmaceutical companies quite extensively use this instrument to demonstrate corporate responsibility (for example in the context of the Accelerating Access Initiative; see IFPMA 2005).

22. Of these funds, $56 \%$ are provided for HIV/AIDS measures like prevention and treatment.

23. For data see: http://www.theglobalfund.org/en/files/pledges\&contributions.xls (accessed 1 May 2006).

24. Source: more than 60 interviews with experts and with staff members of WHO, World Bank, UNAIDS and NGOs conducted for the research project 'Global Health Governance' at the GIGA German Institute of Global and Area Studies.

25. Participation of non-state actors at the country level and good governance are prerequisites for recipient countries to receive money in the MAP. Thus, although the MAP is a programme by an international organization, it empowers non-state actors at the national level and relies on networking.

REFERENCES

Abasi, K. (1999) 'The World Bank and World Health: Changing Sides', British Medical fournal 318(7187): 865-9.

Abbott, F. (2005) 'The WTO Medicines Decision: World Pharmaceutical Trade and the Protection of Public Health', The American fournal of International Law 99(2): 317-58. Abbott, F. (2006) TRIPS II, 'Asia and the Mercantile Pharmaceutical War: Implications for Innovation and Access', Draft Paper for the Conference on Economic Challenges in Asia, Stanford Center for International Development, 31 May-3 June.

Avafia, T., Berger, J. and Hartzenberg, T. (2006) 'The Ability of Select Sub-Sharan African Countries to Utilise TRIPS Flexibilities and Competition Law to Ensure a Sustainable Supply of Essential Medicines: A Study of Producing and Importing Countries', TRALAC Working Paper, Stellenbosch, accessed 25 April 2007, http://www.tralac.org/scripts/content.php?id=5329

Barnett, T. (2006) 'A Long-Wave Event: HIV/AIDS, Politics, Governance and "Security": Sundering the Intergenerational Bond?', International Affairs 82(2): 297-313.

Bartsch, S. (2003) 'Global Public-Private Partnerships in Health: Potentials and Limits', in W. Hein and L. Kohlmorgen (eds) (2003) Globalization, Global Health Governance and National Health Politics in Developing Countries: An Exploration into the Dynamics of Interfaces (pp. 225-40). Hamburg: Schriftendes Deutschen ÜberseeInstitiuts. 
Bartsch, S. (2007) 'The Global Fund to Fight AIDS, Tuberculosis and Malaria', W. Hein, S. Bartsch and L. Kohlmorgen (eds) Global Health Governance and the Fight Against HIVIAIDS (pp. 146-71). Basingstoke: Palgrave Macmillan.

Bartsch, S. and Hein, W. (2003) 'TRIPS und Globale Partnerschaften: Konflikte um den Zugang zu Medikamenten im Rahmen von Global Health Governance' [TRIPS and Global Partnerships: Conflicts on the Access to Drugs in the Context of Global Health Governance], Peripherie 23(90-1): 202-31.

Bartsch, S. and Kohlmorgen, L. (2005) 'Nichtregierungsorganisationen als Akteure der Global Health Governance: Interaktion zwischen Kooperation und Konflikt' [Non-Governmental Organisations as Actors of Global Health Governance: Interaction between Cooperation and Conflict], in J. Betz and W. Hein (eds) Neues Fabrbuch Dritte Welt 2005: Zivilgesellschaft [New Yearbook Third World: Civil Society] (pp. 57-87). Opladen: VS-Verlag.

Bartsch, S. and Kohlmorgen L. (2007) 'The Role of Civil Society Organizations in Global Health Governance', in W. Hein, S. Bartsch and L. Kohlmorgen (eds) Global Health Governance and the Fight Against HIVIAIDS (pp. 92-118). Basingstoke: Palgrave Macmillan.

Braithwaite, J. and Drahos, P. (2000) Global Business Regulation. Cambridge: Cambridge University Press.

Breman, A. and Shelton, C. (2001) 'Structural Adjustment and Health: A Literature Review of the Debate, its Role-Players and Presented Empirical Evidence', CMH Working Paper Series, Paper No. WG6:6. Geneva: WHO, Commission on Macroeconomics and Health.

Brown, T.M., Cueto, M. and Fee, E. (2006) 'The World Health Organization and the Transition from "International" to "Global Health", American Fournal of Public Health 96(1): 62-72.

Burkhalter, H. (2004) 'The Politics of AIDS: Engaging Conservative Activists', Foreign Affairs 83(1): 8-14.

Buse, K. and Gwin, C. (1998) 'The World Bank and Global Cooperation in Health: The Case of Bangladesh', The Lancet 351(9103): 665-9.

Buse, K. and Lee, K. (2005) 'Business and Global Health Governance', Discussion Paper No. 5 - Global Health Governance Series. London: LSHTM, accessed 25 April 2007, http://www.lshtm.ac.uk/cgch/govern.html

Buse, K. and Walt, G. (2002) 'Globalisation and Multilateral Public-Private Health Partnerships: Issues for Health Policy', in K. Lee, S. Fustukian and K. Buse (eds) Health Policy in a Globalising World (pp. 41-62). Cambridge: Cambridge University Press.

Chaudhuri, S. (2005) The WTO and India's Pharmaceutical Industry. Patent Protection, TRIPS, and Developing Countries. Oxford: Oxford University Press.

Collin, J., Lee, K. and Bissell, K. (2005) 'Negotiating the Framework Convention on Tobacco Control: An Updated Politics of Global Health Governance', on R. Wilkinson (ed.) The Global Governance Reader (pp. 252-73). Abingdon: Routledge.

Commission on Intellectual Property Rights and Innovation in Health (CIPIH)/World Health Organization (WHO) (2006) Public Health: Innovation and Intellectual Property Rights. Report of the Commission on Intellectual Property Rights, Innovation and Public Health. Geneva: WHO.

Correa, C. (2002) 'Implications of the Doha Declaration on the TRIPS Agreement and Public Health', Paper commissioned by WHO. Buenos Aires: WHO.

Cueto, M. (2004) 'The Origins of Primary Health Care and Selective Primary Health Care', JLI Working Paper, accessed 12 July 2007, http://www.globalhealthtrust. org/doc/abstracts/WG1/CuetoPAPER.pdf 
DiMasi, J.A., Hamsen, R.W. and Grabowski, H.G. (2003) 'The Price of Innovation: New Estimates of Drug Development Costs', Fournal of Health Economics 22(2): 151-85.

Dodgson, R., Lee, K. and Drager, N. (2002) 'Global Health Governance: A Conceptual Review', LSHTM/WHO Discussion Paper No. 1, accessed 25 April 2007, http://www.lshtm.ac.uk/cgch/globalhealthgovernance.pdf

Fidler, D.P. (2005) 'From International Sanitary Conventions to Global Health Security: The New International Health Regulations', Chinese fournal of International Law 4(2): 325-92.

Ford, N. (2004) 'Patents, Access to Medicines and the Role of Non-Governmental Organisations', Journal of Generic Medicines 1(2): 137-45.

Frost, L. and Reich, M. (1998) Mectizan Donation Program: Origins, Experiences, and Relationships with Co-ordinating Bodies for Onchocereciasis Control. Boston, MA: Department of Population and International Health, Harvard School of Public Health. Global Health Watch (2006) Global Health Watch 2005-2006. London: Zed Press.

Health Action International (HAI) (2001) Public-Private 'Partnerships': Addressing Pulic Health Needs or Corporate Agendas? Report on the HAI Europa/BUKO PharmaKampagne Seminar 3, November 2000, access 25 April 2004, http://www.haiweb. org/campaign/PPI/seminar200011.htm

Hein, W. (2007) 'Global Health Governance and WTO/TRIPS: Conflicts Between "Global Market-Creation" and "Global Social Rights", in W. Hein, S. Bartsch and L. Kohlmorgen (eds) Global Health Governance and the Fight Against HIV/AIDS (pp. 38-66). Basingstoke: Palgrave Macmillan.

Hein, W., Bartsch, S. and Kohlmorgen, L. (eds) (2007) Global Health Governance and the Fight Against HIVIAIDS. Basingstoke: Palgrave Macmillan.

Hein, W. and Kohlmorgen, L. (eds) (2003) Globalisation, Global Health Governance and National Health Politics in Developing Countries: An Exploration into the Dynamics of Interfaces. Hamburg: Schriften des Deutschen Übersee-Instituts.

Held, D. and McGrew, A (eds.) (2002) Governing Globalization. Power, Authority and Global Governance. Cambridge: Polity Press.

Held, D., McGrew, A., Goldblatt, D. and Perraton, J. (1999) Global Transformations. Politics, Economics and Culture. Cambridge: Polity.

IFPMA (International Federation of Pharmaceutical Manufacturers \& Associations) (2005) 'Industry lauds Accelerating Access Initiative (AAI) Progress in Expanding Access to AIDS Drugs', News Release (26 January), Geneva, accessed 25 April 2007, http://www.ifpma.org/News/NewsreleaseDetail.aspx?nID=2330

Ingram, A. (2005) 'Global Leadership and Global Health: Contending Meta-Narratives, Divergent Responses, Fatal Consequences', International Relations 19(4): 381-402.

Kates, J. and Lief, E. (2006) International Assistance for HIV/AIDS in the Developing World: Taking Stock of the G8, Other Donor Governments and the European Commission, Report for the Kaiser Family Foundation. Menlo Park, accessed 25 April 2007, http://www.kff.org/hivaids/7344.cfm

Kaul, I. (2006) 'Exploring the Policy Space between Markets and States. Global PublicPrivate Partnerships', in I. Kaul and P. Conceição (eds) The New Public Finance. Responding to Global Challenges (pp. 219-68). New York: Oxford University Press.

Khagram, S., Riker, J. and Sikkink, K. (eds) (2002) Restructuring World Politics: Transnational Social Movements, Networks and Norms. Minneapolis: University of Minnessota Press.

Kickbusch, I. (2003) 'Global Health Governance: Some New Theoretical Considerations on the New Political Space', in K. Lee (ed.) Globalisation and Health (pp. 192-203). London: Palgrave. 
Koenig-Archibugi, M. and Zürn, M. (eds) (2006) New Modes of Governance in the Global System. Basingstoke: Palgrave Macmillan.

Kohlmorgen, L. (2007) 'International Governmental Organizations and Global Health Governance: The Role of the World Health Organization, World Bank and UNAIDS', in W. Hein, S. Bartsch and L. Kohlmorgen (eds) Global Health Governance and the Fight Against HIV/AIDS (pp. 119-45). Basingstoke: Palgrave Macmillan.

Koivusalo, M. (2003)'Global Governance, Trade and Health Policy', in W. Hein and L. Kohlmorgen (eds) Globalisation, Global Health Governance and National Health Politics in Developing Countries: An Exploration into the Dynamics of Interfaces (pp. 203-24). Hamburg: Schriften des Deutschen Übersee-Instituts.

Kühl, H. (2002) TRIPS and AIDS in South Africa: New Actors in International Relations Weighing Patents, Pills and Patients. Los Angeles, CA: Occidental College.

Lanoszka, A. (2003) 'The Global Politics of Intellectual Property Rights and Pharmaceutical Drugs Policies in Developing Countries', International Political Science Review 24(2): 181-97.

Lee, K. (2003) Globalization and Health: An Introduction. Basingstoke: Palgrave Macmillan.

Lee, K. (2004) 'The Pit and the Pendulum: Can Globalization Take Health Governance Forward?', Development 47(2): 11-17.

Lee, K., Collinson, S., Walt, G. and Gilson, L. (1996) 'Who Should be Doing What in International Health: A Confusion of Mandates in the United Nations?', British Medical fournal 312(7026): 302-7.

Lee, K., Buse, K. and Fustukian, S. (eds) (2002) Health Policy in a Globalizing World. Cambridge: Cambridge University Press.

Loughlin, K. and Berridge, V. (2002) 'Global Health Governance. Historical Dimensions of Global Governance', Centre on Global Change and Health, LSHTM/Department of Health \& Development, WHO, Discussion Paper No. 2. Geneva and London: WHO/LSHTM.

Mayntz, R. (2005) 'Governance Theory als fortentwickelte Steuerungstheorie?' [Governance Theory as Cultivated Theory of Steering?], in G.F. Schuppert (ed.) Governance-Forschung. Vergewisserung über Stand und Entwicklungslinien [Governance Research: Stocktaking on the State of the Art and Trends] (pp. 11-20). BadenBaden: Nomos.

Médecins Sans Frontières (MSF) (2005) Untangling the Web of Price Reductions: A Pricing Guide for the Purchase of ARVs for Developing Countries, 8th Edition (June), accessed 21 June 2007, http://www.accessmed-msf.org/documents/untanglingtheweb\%208.pdf

Micklewright, J. and Wright, A. (2003) 'Private Donations for International Development', Discussion Paper No. 2003/82. Helsinki: WIDER.

Morrison, S.J. (2006) 'What Role for U.S. Assistance in the Fight against Global HIV/AIDS?', Working Paper, The Brookings Institution.

O'Brien, R., Goetz, A.M., Scholte, J.A. and Williams, M. (2000) Contesting Global Governance: Multilateral Economic Institutions and Global Social Movements. Cambridge: Cambridge University Press.

Office of the United States Global AIDS Coordinator (2007) The Power of Partnerships: Third Annual Report to Congress on PEPFAR. Washington, DC: Office of the United States Global AIDS Coordinator.

Ostergard, R.L. (2002) 'Politics in the Hot Zone: AIDS and National Security in Africa', Third World Quarterly 23(2): 333-50.

Oxfam (2002) 'US Bullying on Drug Patents: One Year After Doha', Briefing Paper No. 33. Washington, DC: Oxfam. 
Peterson, S. (2002) 'Epidemic Disease and National Security', Security Studies 12(2): 43-81.

Prins, Gwyn (2004) 'AIDS and Global Security', International Affairs 80(5): 931-52.

Richter J. (2003) 'We the Peoples' or 'We the Corporations'? Critical Reflections on UNBusiness 'Partnerships', IBFAN/GIFA, accessed 255 April 2007, http://www.gifa.org/ Documents/WeThePeopleUNpartnershipsRichter.pdf

Richter, J. (2004) 'Public Private Partnerships and International Health PolicyMaking: How can Public Interests be Safeguarded?’, Policy Brief. Helsinki: GASPP.

Rittberger, V. and Zangl, B. (2006) International Organization - Polity, Politics and Policies. Basingstoke: Palgrave Macmillan.

Rosenau, J.N. (1997) Along the Domestic-Foreign Frontier: Exploring Governance in a Turbulent World. Cambridge: Cambridge University Press.

Schultz, M. and Walker, D. (2005) 'How Intellectual Property Became Controversial: NGOs and the New International IP Agenda', Engage 6(1): 82-98.

Sell, S.K. (2002) 'TRIPS and the Access to Medicines Campaign', Wisconsin International Law fournal 20(3): 481-522.

Sell, S.K. and Prakash, A. (2002) 'Using Ideas Strategically: The Contest Between Business and NGO Networks in Intellectual Property Rights', International Studies Quarterly 48(1): 143-75.

Steiner, H. and Alston, P. (2000) International Human Rights in Context: Law, Politics, Morals, 2nd edn. Oxford: Oxford University Press.

Sturchio, J.L. (2004) 'Partnership for Action: The Experience of the Accelerating Access Initiative, 2000-2004, and Lessons Learned', in A. Attaran and B. Granville, Delivering Essential Medicines (pp. 117-51). London: Royal Institute of International Affairs.

't Hoen, E. (2002) 'TRIPS, Pharmaceutical Patents and Access to Essential Medicines: A Long Way from Seattle to Doha', Chicago fournal of International Law 3(1): 27-48. Thomas, C. and Weber, M. (2004) 'The Politics of Global Health Governance: Whatever Happened to "Health for All by the Year 2000"?', Global Governance 10(2): 187-205.

UNAIDS (2006) 2006 Report on the Global AIDS Epidemic: A UNAIDS 10th Anniversary Special Edition. Geneva: UNAIDS.

Vasan, A., Hoos, D., Mukherjee, J.S., Farmer, P.E., Rosenfield, A.G. and Perriëns, J.H. (2006) 'The Pricing and Procurement of Antiretroviral Drugs: An Observational Study of Data from the Global Fund', Bulletin of the World Health Organization 84(5): 393-8.

Vivas-Eugui, D. (2003) Regional and Bilateral Agreements and a TRIPS-Plus World: The Free Trade Area of the Americas (FTAA). Geneva: QUNO, QIAP, ICTSD.

Wade, R.H. (2003) What Strategies are Viable for Developing Countries Today? The World Trade Organization and the Shrinking of 'Development Space'. London: LSE, Crisis States Programme.

Weissman, R. (2001) 'AIDS and Developing Countries: Facilitating Access to Essential Medicines', Policy Brief, Foreign Policy in Focus 6(6), Accessed 15 November 2007, http://www.fpif.org/briefs/vol6/v6n06aids.html

Widdus, R. (2001) 'Public-Private Partnerships for Health: Their Main Targets, Their Diversity, and Their Future Directions', Bulletin of the World Health Organization 79(8): 713-20.

Wilkinson, R. (ed.) (2005) The Global Governance Reader. London: Routledge.

Wogart, J.P. and Calcagnotto, G. (2006) 'Brazil's Fight against AIDS and its Implications for Global Health Governance', Healthcare Quarterly 9(1): 90-103. 
Wolfensohn, J. (2004) 'World Bank Meeting: The Growing Threat of Global Poverty', International Herald Tribune (24 April), accessed 15 November 2007, http://www.iht.com/articles/2004/04/24/edwolf_ed3_.php

World Health Organization (WHO) (1978) Declaration of Alma Ata 1978. Geneva: WHO, accessed 9 January 2006, http://www.who.int/hpr/NPH/docs/declaration_almaata.pdf

World Health Organization (WHO) (2006) Progress on Global Access to HIV Antiretroviral Therapy: A Report on '3 by 5' and Beyond, accessed 15 November 2007, http://www.who.int/hiv/progreport2006_en.pdf

Yamey, G. (2002) 'WHO in 2002: Why Does the World Still need WHO?', British Medical fournal 325(7375): 1294-8.

Zwi, A.B., Fustukian, S. and Sethi, D. (2002) 'Globalisation, Conflict and the Humanitarian Response', in K. Lee, K. Buse and S. Fustukian (eds) Health Policy in a Globalising World (pp. 229-50). Cambridge: Cambridge University Press.

RÉSUMÉ

\section{La Gouvernance de la Santé Globale: Les Conflits à Propos des Droits Sociaux Globaux}

Ce papier analyse l'effet des nouvelles structures institutionnelles dans la gouvernance de la santé globale sur la réalisation des droits sociaux dans les pays pauvres. Dans ce document on considère l'exemple de la politique globale du SIDA/VIH. Le papier soutient que des nouveaux modes de gouvernance augmentent la participation des groupes de société civile et des communautés affectés, mais suggère qu'ils sont aussi fréquemment instrumentalisés par des acteurs puissants qui cherchent à poursuivre leurs propres intérêts. En fait, on mobilise d'autant plus de ressources dans la lutte contre les maladies liées à la pauvreté. Le papier conclut que la gouvernance de la santé globale est caractérisée par une combinaison de valeurs morales et d'intérêts matériaux qui ne garantissent pas une réalisation compréhensive des droits sociaux - ce qui a été suggéré par notre expérience dans la politique du SIDA/VIH, les conflits autour de l'Accord 'TRIPS', et le développement des 'GPPPs'. Cependant, ces valeurs et ces intérêts permettent un certain taux de progrès dans la lutte contre les maladies liées à la pauvreté - ce qui est nécessaire pour la possible réalisation des droits sociaux.

\section{RESUMEN}

\section{La Gestión de la Salud Global: Conflictos Sobre los Derechos Sociales Globales}

El siguiente trabajo analiza el impacto de las nuevas estructuras institucionales en la gestión de la salud global sobre la realización de los derechos sociales en los países pobres. En este documento tomamos en cuenta el ejemplo de la política del SIDA/VIH. El artículo propone que los nuevos métodos de gestión aumentan la participación de grupos de sociedad civil y de las comunidades afectadas, pero debate que están frecuentemente instrumentalizadas por actores poderosos que buscan a seguir sus propios intereses. De hecho, se movilizan más y más recursos en la lucha contra las 
enfermedades relacionadas con la pobreza. El documento concluye que - como sugiere nuestra experiencia con los conflictos sobre el 'Acuerdo TRIPS', la política del SIDA/VIH, y el desarrollo de los 'GPPPs' - la gestión de la salud global está caracterizada por una combinación de valores morales e intereses materiales que no garantizan una realización comprensiva de los derechos sociales. Permiten, sin embargo, algunos avances en la lucha contra las enfermedades relacionadas con la pobreza - lo que es un requisito para la posible realización de los derechos sociales.

BIOGRAPHICAL NOTE

WOLFGANG HEIN is head of the research unit 'Transformation in the Process of Globalisation' at the GIGA German Institute of Global and Area Studies, focusing on various aspects of research on development and North-South relations (theories of development, agro-industrial links, sustainable development in Central America, globalization and global governance). He teaches at the University of Hamburg. From 1978 to 1988 he was assistant professor at the Institute of Latin American Studies at the Free University of Berlin. He has published a number of edited volumes and monographs in the field of development, globalization and global health governance. $\mathrm{He}$ is the co-editor of two German reviews in the development field (Peripherie, Lateinamerika Analysen) and directs the GIGA project on global health governance. Please address correspondence to: Professor Dr Wolfgang Hein, GIGA German Institute of Global and Area Studies, Neuer Jungfernstieg 21, 20354 Hamburg, Germany. [email: hein@giga-hamburg.de]

LARS KOHLMORGEN is a senior research fellow and lecturer at the Institute of Political Sciences, University of Hamburg and associated research fellow at the GIGA German Institute of Global and Area Studies. Besides global health governance, his current research and publishing work focuses on global governance in general, international relations theory, development policy, global social policy, international organizations, civil society organizations and intellectual property rights. Prior to working for the University of Hamburg and GIGA, he completed his PhD in Social Science at the University of Hamburg with a scholarship by the Hans-Boeckler-Foundation. Please address correspondence to: Dr Lars Kohlmorgen, GIGA German Institute of Global and Area Studies, Neuer Jungfernstieg 21, 20354 Hamburg, Germany. [email: kohlmorgen@giga-hamburg.de] 